\title{
Evaluation of Shrubs for Side Slope Greening and Protection in Urban Landscape
}

\author{
Gabriele Amoroso ${ }^{1,3}$, Piero Frangi ${ }^{1}$, Riccardo Piatti ${ }^{1}$, Alessio Fini $^{2}$, \\ Francesco Ferrini $^{2}$, and Marco Faoro ${ }^{1}$
}

ADDITIONAL INDEX WORDs. mulch, low-maintenance, ornamental value, plant management, revegetation, weed control

SumMARY. Shrubs are often used for side slope greening and protection in the urban landscape. Only a few species are commonly used in the European city environment, bestowing upon cities a monotonous appearance. The aim of this 3-year trial, set up at Fondazione Minoprio (Vertemate con Minoprio; Como, Italy), was to evaluate the performance of $\mathbf{2 5}$ shrub species grown on a slope during three seasons (2007-09). Moreover, to evaluate the influence of weeds on plant growth and the weeding time, two mulches (biodegradable textile and polypropylene fabric) were used in comparison with bare soil (control). Shrubs were planted in late Spring 2007. To simulate urban conditions, no pruning or disease control were applied. Irrigation was carried out only in the driest periods of the first summer. Plant height and percent cover were measured every 2 months, whereas plant phenology and state of health were recorded weekly. Chlorophyll fluorescence and chlorophyll content were evaluated on two different drought-tolerant species during the third growing season. At the end of the trial shoot biomass was measured and root characteristics (root density and specific root length) were determined. Weeds were removed twice in the first and third years and three times in the second year. Time for weed removal was recorded for each experimental plot. Results show that the highest growth (height and biomass) was detected in mulched plots, probably because of both limited weed competition for water and nutrients and lower water loss by evaporation. Plants grown in bare soil showed higher root density and finer roots compared with mulched plants; this may be explained by the necessity of the plant root system to explore the soil to reach for water. Differences in growth, groundcovering, and root characteristics were observed among species. As a result of higher mulching cost and the poorer root characteristics of mulched plants, bare soil and fast growing shrubs should be used to limit weed competition and assure a satisfactory slope greening and consolidation.

$\mathrm{D}$ uring the last few years only a few species have been regularly used in the European urban landscape [i.e., herbaceous species or evergreen shrubs such as cotoneaster (Cotoneaster spp.) and honeysuckle (Lonicera spp.)], but many other species and cultivars could be suitable for this purpose (Assone et al., 2000). Current trends in urban landscaping require the use of lowmaintenance species in response to the reduced water availability for

\footnotetext{
This work was conducted under a research project "ARBOVERDE-Valutazione di specie arbustive ornamentali per il rinverdimento di scarpate" financed by Regione Lombardia - Agricultural Department, according to the Plan of Research and Development 2006. We gratefully acknowledge Professor Daniel K. Struve (Department of Horticulture and Crop Science, The Ohio State University) for his critical review of the manuscript.

${ }^{1}$ Fondazione Minoprio, Centro MiRT, Viale Raimondi, 54, 22070 Vertemate con Minoprio (CO), Italy

${ }^{2}$ Department of Plant, Soil and Environmental Science, University of Florence, Viale delle Idee, 30, 50019 Sesto Fiorentino (FI), Italy

${ }^{3}$ Corresponding author. E-mail: g.amoroso@ fondazioneminoprio.it.
}

irrigation of urban greenspaces and to the low skill of the maintenance workforce (Franco et al., 2006). Moreover, it is necessary to limit weed competition with transplanted plants to reduce the need for weeding and chemical treatments. Mulch could be successfully used for this purpose (Chalker-Scott, 2007; Ferrini et al., 2008; Stinson et al., 1990). Mulching benefits plant growth and improvement of soil characteristics (Chalker-Scott,
2007), but little information is available on mulch effect on root characteristics of shrub species.

The importance of vegetation on erosion control and slope consolidation is widely documented. In general, vegetation stabilizes slopes (Cazzuffi and Tironi, 2003; Macdonald and Witek, 1994; Stokes et al., 2009). The protective role of vegetation can be explained by many different hydromechanical mechanisms ranging from mechanical reinforcement and restraint by the roots to modification of slope hydrology as a result of rain drop interception by the foliage and soil moisture extraction through transpiration (Gray and Leiser, 1982; Gray and Satir, 1996; Morgan and Rickson, 1994). In urban areas, grass, forbs, or shrubs can be used for slope covering. Grass or other herbaceous vegetation provide protection against rain and wind erosion of surface soils. Conversely, shrubs are more effective in stabilizing soil due to their deep roots (Gray and Satir, 1996). The objective of this work was to measure shoot growth and root characteristics of 25 shrubs species over 3 years under a low-maintenance regime and three mulching systems.

\section{Materials and methods}

This experiment was carried out at Fondazione Minoprio (Vertemate con Minoprio, Como, Italy) (lat. $45^{\circ} 44^{\prime} \mathrm{N}$, long. $9^{\circ} 04^{\prime} \mathrm{E}$, elevation $342 \mathrm{~m}$ ) over 3 years (2007-09). Daily temperature and rainfall were recorded and monthly averages reported (Fig. 1). The study area was a uniform south-facing slope at a $45^{\circ}$ average inclination angle. Before planting, two herbicide treatments were made on 11 Nov. 2006 and 14 Mar. 2007 using broadcast glyphosate (Roundup ${ }^{\circledR} 450$ Plus; Monsanto, Creve Coeur, MO) and pendimethalin (Stomp ${ }^{\circledR} 330-E ;$ BASF, Ludwigshafen,

\begin{tabular}{llll}
\hline $\begin{array}{l}\text { Units } \\
\begin{array}{l}\text { To convert U.S. to SI, } \\
\text { multiply by }\end{array}\end{array}$ & U.S. unit & SI unit & $\begin{array}{l}\text { To convert SI to U.S., } \\
\text { multiply by }\end{array}$ \\
\hline 29.5735 & $\mathrm{fl} \mathrm{oz}$ & $\mathrm{mL}$ & 0.0338 \\
0.3048 & $\mathrm{ft}$ & $\mathrm{m}$ & 3.2808 \\
0.0929 & $\mathrm{ft}^{2}$ & $\mathrm{~m}^{2}$ & 10.7639 \\
3.7854 & gal & $\mathrm{L}$ & 0.2642 \\
2.54 & inch $(\mathrm{es})$ & $\mathrm{cm}$ & 0.3937 \\
25.4 & inch(es) & $\mathrm{mm}$ & 0.0394 \\
16.3871 & inch & $\mathrm{cm}^{3}$ & 0.0610 \\
1.1209 & lb/acre & $\mathrm{kg} \cdot \mathrm{ha}^{-1}$ & 0.8922 \\
28.3495 & $\mathrm{oz}$ & $\mathrm{g}$ & 0.0353 \\
62.5000 & $\mathrm{oz} / \mathrm{lb}$ & $\mathrm{g} \cdot \mathrm{kg}^{-1}$ & 0.0160 \\
$\left({ }^{\circ} \mathrm{F}-32\right) \div 1.8$ & ${ }^{\circ} \mathrm{F}$ & ${ }^{\circ} \mathrm{C}$ & $\left(1.8 \times{ }^{\circ} \mathrm{C}\right)+32$
\end{tabular}


Germany) at 38 and $16 \mathrm{~mL} / 100 \mathrm{~L}$, respectively. Ten soil samples were randomly collected from the site and analyzed in Jan. 2007 (Table 1) (Osmond et al., 1997). On the basis of the soil analysis, calcium carbonate $\left(1500 \mathrm{~kg} \cdot \mathrm{ha}^{-1}\right)$ and $5 \mathrm{~N}-4.5 \mathrm{P}-25 \mathrm{~K}$ $\left(750 \mathrm{~kg} \cdot \mathrm{ha}^{-1}\right)$ mineral fertilizer were incorporated $7 \mathrm{~cm}$ into the surface in March. In early May 2007, 25 shrub species (Table 2) were obtained from local nurseries in $3-\mathrm{L}$ containers. Shrubs were planted at a density of 4 plants $/ \mathrm{m}^{2}$. Within a species, all plants came from the same Italian nursery, but not all species came from the same nursery. Two mulches: 1) black polypropylene fabric $(3210 \mathrm{NE}$ Agritela; Arrigoni, Uggiate Trevano, Italy) and 2 ) biodegradable textile made of natural fibers [coconut (Cocos nucifera), cotton (Gossypium spp.), and jute (Corchorus olitorius)] [80 $\mathrm{g} \cdot \mathrm{m}^{-2}$ (Isonatural $\AA$; Veris srl, Codogno, Italy)], and a non-mulch control were used.

The experiment was a split-plot design with three replicates, where soil management was the main plot and species was the subplot. The size of each subplot was $8 \mathrm{~m}^{2}$ for a total experimental area of $1800 \mathrm{~m}^{2}$. Two hundred and eighty-eight plants for each species were used in the experiment for a total of 7200 plants. No irrigation or pruning was carried out during the trial, except in the first summer (2007) when plants were weekly irrigated during the driest weeks using a drip irrigation system (seven irrigation events delivering $10 \mathrm{~mm} \cdot \mathrm{h}^{-1}$, the irrigation was carried out over $3 \mathrm{~h}$ ). According to the standard weed management (Rice, 1992), herbicides were applied as a granular broadcast application twice during 2007 on the nonmulched plots: isoxaben + trifluralin [Gallery® T-DG (Dow Agroscience, Indianapolis, IN) at $20.5 \mathrm{~kg} \cdot \mathrm{ha}^{-1}$ ] and $3.6 \mathrm{~kg} \cdot \mathrm{ha}^{-1}$ oxadiazon (Ronstar ${ }^{\circledR}$; Bayer CropScience, Monheim am Rhein, Germany).

Canopy height and percent cover were measured bimonthly during the experiment. Plant height was measured on four randomized plants per subplots while percent cover was assessed visually using a four class scale: $1=<25 \%$, $2=25 \%$ to $50 \%, 3=50 \%$ to $75 \%$, and $4=>75 \%$. Plant disease symptoms and phenology were recorded weekly. Weeds were removed by hand twice in the first and third growing seasons and three times during the second growing

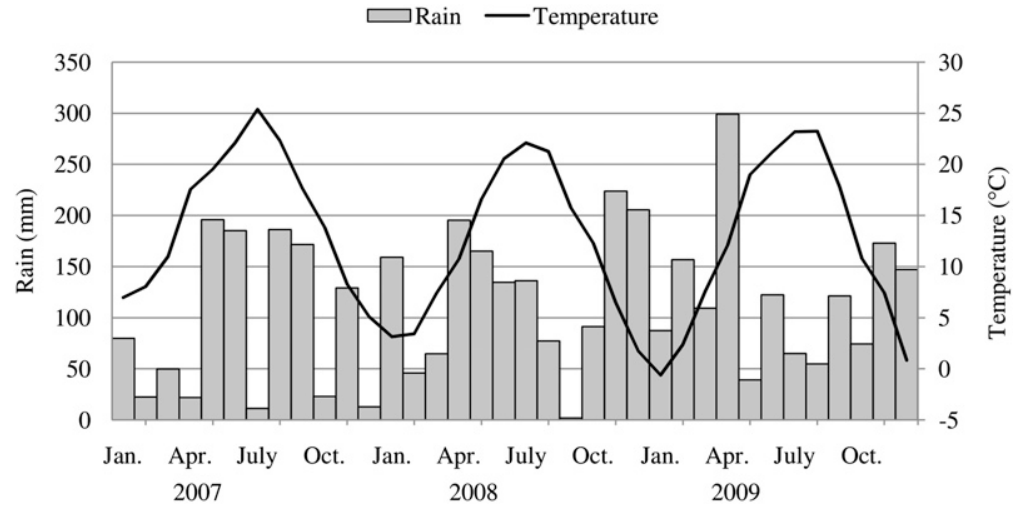

Fig. 1. Monthly average temperature and monthly rainfall over 3 years (2007-09); $\left(1.8 \times{ }^{\circ} \mathrm{C}\right)+32={ }^{\circ} \mathrm{F}, 1 \mathrm{~mm}=0.0394$ inch.

Table 1. Soil physical and chemical properties at the beginning of the trial (Jan. 2007). The parameters reported in the table were obtained collecting soil samples in 10 randomly zones in the slope area. Soil samples were collected at $20-\mathrm{cm}$ (7.9 inches) depth.

\begin{tabular}{|c|c|c|c|c|c|}
\hline $\begin{array}{l}\text { Gravel > } 2 \\
\mathrm{~mm}\left(\mathrm{~g} \cdot \mathrm{kg}^{-1}\right)^{\mathrm{z}} \\
\end{array}$ & $\begin{array}{c}\text { Sand }<2 \\
\mathrm{~mm}\left(\mathrm{~g} \cdot \mathrm{kg}^{-1}\right)\end{array}$ & $\begin{array}{c}\text { Silt }<0.05 \\
\mathrm{~mm}\left(\mathrm{~g} \cdot \mathrm{kg}^{-1}\right)\end{array}$ & $\begin{array}{c}\text { Clay }<0.002 \\
\mathrm{~mm}\left(\mathrm{~g} \cdot \mathrm{kg}^{-1}\right)\end{array}$ & $\mathrm{pH}$ & $\begin{array}{c}\text { Carbon/ } \\
\text { nitrogen ratio }\end{array}$ \\
\hline 202.4 & 565.1 & 412.3 & 22.6 & 6.45 & 11.16 \\
\hline
\end{tabular}

${ }^{\mathrm{z}} 1 \mathrm{~mm}=0.0394$ inch, $1 \mathrm{~g} \cdot \mathrm{kg}^{-1}=0.0160 \mathrm{oz} / \mathrm{lb}$.

Table 2. List of the $\mathbf{2 5}$ shrubs planted on a slope to evaluate their establishment, root characteristics, and canopy groundcover ability under low-maintenance conditions in different types of soil management (bare soil and mulching with biodegradable textile or polypropylene fabric).

\begin{tabular}{ll}
\hline Common name & \multicolumn{1}{c}{ Scientific name } \\
\hline Blue-spirea & Caryopteris $\times$ clandonensis \\
& 'Heavenly Blue' \\
Border forsythia & Forsythia $\times$ intermedia 'Lynwood' \\
Boxleaf honeysuckle & Lonicera nitida \\
Bumald spirea & Spiraea japonica 'Anthony Waterer' \\
Bush cinquefoil & Potentilla fruticosa 'Goldfinger' \\
Buttercup winterhazel & Corylopsis pauciflora \\
Common ninebark & Physocarpus opulifolius 'Diablo' \\
Common seabuckthorn & Hippophae rhamnoides \\
Doublefile viburnum & Viburnum plicatum 'Shasta' \\
English ivy & Hedera helix 'Gold heart' \\
Fragrant viburnum & Viburnum farreri \\
Fuzzy deutzia & Deutzia scabra 'Pride of Rochester' \\
Glossy abelia & Abelia $\times$ grandiflora \\
Goldencup st. johnswort & Hypericum patulum 'Hidcote' \\
Hybrid deutzia & Deutzia hybrida 'Strawberry Fields' \\
Japanese kerria & Kerria japonica 'Picta' \\
Privet honeysuckle & Lonicera pileata \\
Purpleosier willow & Salix purpurea 'Nana' \\
Redosier dogwood & Cornus sericea 'Kelseyi' \\
Scorpion senna & Coronilla emerus (synonym: \\
Shrub althea & Hippocrepis emerus) \\
Slender deutzia & Hibiscus syriacus \\
Spanish broom & Deutzia gracilis \\
Spanish gorse & Spartium junceum \\
Virginal mock orange & Genista lydia \\
& Philadelphus $\times$ virginalis \\
& 'Minnesota Snowflake' \\
\hline &
\end{tabular}


season. Time needed for weed removal was recorded for each experimental subplot. At the end of the 2 nd year, because of the high mortality in non-mulched subplots, doublefile viburnum, english ivy, and fragrant viburnum were excluded from the experiment. In the third growing season leaf chlorophyll content, the maximal quantum yield of photosystem II [variable fluorescence $\left(F_{\mathrm{V}}\right) /$ maximum fluorescence $(F \mathrm{~m})]$ and fluorescence transient were measured on goldencup st. johnswort and shrub althea [considered drought-tolerant (Burroughs, 2010) and drought-sensitive (Yeager et al., 2006) species, respectively]. Leaf chlorophyll content was measured on 25 June, 3 July, and 6 Aug. with a chlorophyll meter (SPAD502; Minolta, Osaka, Japan) on five randomly chosen plants per block (for a total of 30 plants per species). Three youngest fully expanded leaves for each plant were used for this assessment. A clear relationship between chlorophyll meter readings and total leaf chlorophyll concentration was reported by Percival et al. (2008). Fv/ $F \mathrm{~m}$ and fluorescence transient were measured three times during the driest period of the third growing season (on 3 July, 6 Aug., and 26 Aug. using five randomly selected plants per subplot and one fully expanded leaf per plant). Leaves were adapted to the dark for 30 min before $F_{\mathrm{v}} / F \mathrm{~m}$ and fluorescence transient measurements using shading clips. Determinations of $F_{\mathrm{V}} / F_{\mathrm{m}}$ and fluorescence transient were carried out using a portable fluorimeter (Handy Pea Plant Efficiency Analyser; Hansatech Instruments, Norfolk, United Kingdom) and recorded for up to $1 \mathrm{~s}$, with data acquisition every $10 \mu$ s for the first $2 \mathrm{~ms}$, and every $1 \mathrm{~ms}$ thereafter, with 12-bit resolution (Strasser et al., 2000). The fluorescence transients were introduced by red light (peak at $650 \mathrm{~nm}$ ) at $600 \mu \mathrm{mol} \cdot \mathrm{m}^{-2} \cdot \mathrm{s}^{-1}$ photons provided by an array of six light-emitting diodes. Upon the application of a saturating flash of actinic light, fluorescence raises from the ground state value $\left(F_{0}\right)$ to its maximum value, $F \mathrm{~m}$. This allows the determination of the maximal quantum yield of photosystem II $\left(F_{\mathrm{V}} / F \mathrm{~m}\right)$ (Pinior et al., 2005). Fluorescence values at time intervals corresponding to the step O-J-I-P were recorded and used as original data in the OJIP-test (Strasser and Tsimilli-Michael, 2001).
These include the $F \mathrm{~m}$ (step P), the fluorescence intensity at $50 \mu \mathrm{s}\left[F_{0}\right.$ (step $\mathrm{O})], 100 \mu \mathrm{s}\left(F_{100}\right), 300 \mu \mathrm{s}\left(F_{300}\right), 2 \mathrm{~ms}$ (step J), and $30 \mathrm{~ms}$ (Step I).

In Dec. 2009, four plants per subplot were cut at the root flare and fresh biomass determined by weighing the plants in the field with a digital balance (440-53N; Kern \& Sohn, Balingen-Frommern, Germany) (36 plants per species). Four soil cores were collected randomly from each subplot in Dec. 2009 using a plant root sampler (Profile sampler 05.08; Eijkelkamp, Giesbeek, The Netherlands).

Table 3. Hand weeding time required in each growing season (weed removal was carried out twice during the first and third growing season and three times during the second growing season) for 25 shrubs grown on a slope under different types of soil management (bare soil and mulched with biodegradable textile or polypropylene fabric). Shrubs were transplanted at a density of 4 plants $/ \mathrm{m}^{2}\left(0.37\right.$ plant $\left./ \mathrm{ft}^{2}\right)$ in May 2007 from 3-L $(0.8 \mathrm{gal})$ containers.

\begin{tabular}{|c|c|c|c|c|c|c|c|c|}
\hline & \multicolumn{8}{|c|}{ Hand weeding time $\left(s \cdot m^{-2}\right)^{z}$} \\
\hline & \multicolumn{2}{|c|}{2007} & \multicolumn{2}{|c|}{2008} & \multicolumn{2}{|c|}{2009} & \multicolumn{2}{|c|}{ Total } \\
\hline & & & & & & \multicolumn{3}{|c|}{ Species (SP) } \\
\hline Blue-spirea & 66 & $c-e^{y}$ & 116 & $\mathrm{i}-\mathrm{k}$ & 50 & $\mathrm{~cd}$ & 232 & $\mathrm{e}-\mathrm{g}$ \\
\hline Border forsythia & 92 & $\mathrm{c}-\mathrm{e}$ & 145 & $\mathrm{~g}-\mathrm{k}$ & 24 & $\mathrm{~d}$ & 261 & $\mathrm{~d}-\mathrm{g}$ \\
\hline Boxleaf honeysuckle & 85 & $\mathrm{c}-\mathrm{e}$ & 260 & $\mathrm{~b}-\mathrm{d}$ & 61 & $\mathrm{~b}-\mathrm{d}$ & 406 & $\mathrm{bc}$ \\
\hline Bumald spirea & 87 & $\mathrm{c}-\mathrm{e}$ & 153 & $\mathrm{f}-\mathrm{k}$ & 9 & $\mathrm{~d}$ & 249 & $d-g$ \\
\hline Bush cinquefoil & 82 & $\mathrm{c}-\mathrm{e}$ & 175 & $e-j$ & 46 & $\mathrm{~cd}$ & 303 & $c-f$ \\
\hline Buttercup winterhazel & 74 & $\mathrm{c}-\mathrm{e}$ & 188 & $\mathrm{~d}-\mathrm{i}$ & 42 & $\mathrm{~cd}$ & 304 & $c-f$ \\
\hline Common ninebark & 60 & de & 135 & $\mathrm{~g}-\mathrm{k}$ & 22 & $\mathrm{~d}$ & 217 & $d-f$ \\
\hline Common seabuckthorn & 118 & $\mathrm{bc}$ & 250 & $\mathrm{c}-\mathrm{e}$ & 128 & $\mathrm{ab}$ & 496 & $\mathrm{~b}$ \\
\hline Doublefile viburnum & 77 & $\mathrm{c}-\mathrm{e}$ & 214 & $\mathrm{~d}-\mathrm{g}$ & \multicolumn{2}{|c|}{-} & \multicolumn{2}{|c|}{ - } \\
\hline English ivy & 157 & $\mathrm{ab}$ & 348 & $\mathrm{a}$ & \multicolumn{2}{|c|}{ - } & \multicolumn{2}{|c|}{-} \\
\hline Fragrant viburnum & 76 & ce & 206 & $\mathrm{~d}-\mathrm{h}$ & \multicolumn{2}{|c|}{-} & \multicolumn{2}{|c|}{-} \\
\hline Fuzzy deutzia & 102 & $\mathrm{c}-\mathrm{e}$ & 112 & $\mathrm{i}-\mathrm{k}$ & 16 & $\mathrm{~d}$ & 230 & $\mathrm{e}-\mathrm{g}$ \\
\hline Glossy abelia & 74 & $\mathrm{c}-\mathrm{e}$ & 120 & $\mathrm{i}-\mathrm{k}$ & 15 & $\mathrm{~d}$ & 209 & $\mathrm{e}-\mathrm{g}$ \\
\hline Goldencup st. johnswort & 105 & $\mathrm{c}-\mathrm{e}$ & 102 & $\mathrm{i}-\mathrm{k}$ & 12 & $\mathrm{~d}$ & 219 & $\mathrm{e}-\mathrm{g}$ \\
\hline Hybrid deutzia & 100 & $\mathrm{c}-\mathrm{e}$ & 100 & $\mathrm{jk}$ & 11 & $\mathrm{~d}$ & 211 & $\mathrm{e}-\mathrm{g}$ \\
\hline Japanese kerria & 109 & $\mathrm{~cd}$ & 170 & $e-j$ & 72 & $\mathrm{ad}$ & 351 & $\mathrm{c}-\mathrm{e}$ \\
\hline Privet honeysuckle & 79 & $\mathrm{c}-\mathrm{e}$ & 331 & $\mathrm{ab}$ & 120 & $a-c$ & 530 & $\mathrm{ab}$ \\
\hline Purpleosier willow & 54 & $\mathrm{e}$ & 72 & $\mathrm{k}$ & 10 & $\mathrm{~d}$ & 136 & $\mathrm{~g}$ \\
\hline Redosier dogwood & 64 & de & 140 & $\mathrm{~g}-\mathrm{k}$ & 44 & $\mathrm{~cd}$ & 248 & $\mathrm{~d}-\mathrm{g}$ \\
\hline Scorpion senna & 68 & $\mathrm{c}-\mathrm{e}$ & 107 & $\mathrm{i}-\mathrm{k}$ & 52 & $b-d$ & 227 & $\mathrm{e}-\mathrm{g}$ \\
\hline Shrub althea & 101 & $\mathrm{c}-\mathrm{e}$ & 172 & $e-j$ & 64 & $\mathrm{ad}$ & 337 & $\mathrm{c}-\mathrm{f}$ \\
\hline Slender deutzia & 94 & $\mathrm{c}-\mathrm{e}$ & 234 & $d-f$ & 67 & $a-d$ & 395 & $b-d$ \\
\hline Spanish broom & 60 & de & 126 & $\mathrm{~h}-\mathrm{k}$ & 0 & $\mathrm{~d}$ & 186 & $f-g$ \\
\hline Spanish gorse & 192 & $\mathrm{a}$ & 311 & $\mathrm{ac}$ & 138 & $\mathrm{a}$ & 641 & $\mathrm{a}$ \\
\hline Virginal mock orange & 72 & $\mathrm{c}-\mathrm{e}$ & 135 & $\mathrm{~g}-\mathrm{k}$ & 15 & $\mathrm{~d}$ & 222 & $\mathrm{e}-\mathrm{g}$ \\
\hline \multicolumn{9}{|l|}{ Weed management (WM) } \\
\hline Polypropylene fabric & 47 & $\mathrm{~b}$ & 109 & $\mathrm{~b}$ & 14 & $\mathrm{~b}$ & 170 & $\mathrm{~b}$ \\
\hline Biodegradable textile & 44 & $\mathrm{~b}$ & 121 & $\mathrm{~b}$ & 24 & $\mathrm{~b}$ & 189 & $\mathrm{~b}$ \\
\hline Bare soil & 174 & $\mathrm{a}$ & 301 & $\mathrm{a}$ & 106 & $\mathrm{a}$ & 581 & $\mathrm{a}$ \\
\hline \multicolumn{9}{|l|}{ Probability } \\
\hline SP & \multicolumn{2}{|c|}{$* * *$} & \multicolumn{2}{|c|}{$* * *$} & \multicolumn{2}{|c|}{$* * *$} & \multicolumn{2}{|c|}{$* * *$} \\
\hline WM & \multicolumn{2}{|c|}{$* * *$} & \multicolumn{2}{|c|}{$* * *$} & \multicolumn{2}{|c|}{$* * *$} & \multicolumn{2}{|c|}{$* * *$} \\
\hline $\mathrm{SP} \times \mathrm{WM}$ & \multicolumn{2}{|c|}{ NS } & \multicolumn{2}{|c|}{ NS } & \multicolumn{2}{|c|}{ NS } & \multicolumn{2}{|c|}{ NS } \\
\hline
\end{tabular}

The volume of soil cores was 1250 $\mathrm{cm}^{3}(25 \times 10 \times 5 \mathrm{~cm})$. Samples were collected in between two plants of the same species $(\approx 70 \mathrm{~cm}$ from the root flares). After sampling, collected cores were separated in two sections: 0-10 $\mathrm{cm}$ and 10-25 cm deep. Samples were placed in plastic bags and held at $7{ }^{\circ} \mathrm{C}$ until January. In Jan. 2010, samples were sifted twice first over a $0.5 \mathrm{~cm}$ grid and then over a $0.2 \mathrm{~cm}$. Root length was estimated by the intercept method (Tennant, 1975). Root samples were oven-dried $\left(104^{\circ} \mathrm{C}\right)$, and dry weights were recorded. Root density 
was calculated as root length over soil volume ratio [root length/soil volume (meters per liter)], and specific root length was calculated as the ratio between root length and root dry biomass [root length/root dry biomass (meters per gram)].

All data were processed with analysis of variance, or multivariate analysis of variance when two effects acted in combination. SPSS $₫$ (version 17.0; SPSS, Chicago, IL) was used. Means were separated by Duncan's multiple range test at a $P \leq 0.05$ level of significance.

\section{Results and discussion}

Without mulch, more time was required for weeding (Table 3 ). Despite the evident degradation shown by the biodegradable textile during the third growing season, no differences in hand weeding time were observed between plants mulched with this material and with polypropylene fabric over the experiment duration (Table 3). During the first two growing seasons complete canopy closure did not occur and the sunlight could reach the soil. During this period weed control by the biodegradable textile was very important in reducing weed competition with the shrubs, allowing the growth of a shading shrub canopy. After this period the mulch importance as weed regulator was decreased, but the degradation of the material did not affect the weed removal time.

Weeding spanish gorse subplots required the most hand labor, whereas purpleosier willow required the least (Table 3). Blue-spirea, border forsythia, bumald spirea, fuzzy deutzia, glossy abelia, goldencup st. johnswort, hybrid deutzia, redosier dogwood, scorpion senna, spanish broom, virginal mock orange, and purpleosier willow had the lowest hand weeding times (Table 3 ). Those species with the most rapid canopy closure required the least weeding time. At the end of the first growing season, blue-spirea, japanese kerria, scorpion senna, and spanish broom performed the highest percent cover regardless of the soil management. At the end of the second growing season, only english ivy, privet honeysuckle, spanish gorse, and fragrant viburnum showed the lowest values of canopy closure (Table 4 ). In relation to weed management, the polypropylene fabric allowed the highest groundcover ability

Table 4. Groundcover ability of 25 shrubs grown on a slope under different types of soil management (bare soil and mulched with biodegradable textile or polypropylene fabric). Shrubs were transplanted at a density of 4 plants $/ \mathrm{m}^{2}$ $\left(0.37\right.$ plant $\left./ \mathrm{ft}^{2}\right)$ in May 2007 from $3-\mathrm{L}(0.8 \mathrm{gal})$ containers.

\begin{tabular}{|c|c|c|c|c|c|c|}
\hline & \multicolumn{6}{|c|}{ Canopy groundcover $(1-4 \text { scale })^{\mathrm{z}}$} \\
\hline & \multicolumn{2}{|c|}{ Oct. 2007} & \multicolumn{2}{|c|}{ Oct. 2008} & \multicolumn{2}{|c|}{ Oct. 2009} \\
\hline \multicolumn{7}{|l|}{ Species $(\mathrm{SP})$} \\
\hline Blue-spirea & 3.89 & $a^{y}$ & 4.00 & $\mathrm{a}$ & 4.00 & $\mathrm{a}$ \\
\hline Border forsythia & 2.89 & ef & 3.33 & $\mathrm{~b}-\mathrm{f}$ & 3.89 & $\mathrm{ab}$ \\
\hline Boxleaf honeysuckle & 2.00 & hi & 2.78 & $\mathrm{f}$ & 3.44 & $\mathrm{a}-\mathrm{c}$ \\
\hline Bumald spirea & 2.33 & gh & 3.44 & $\mathrm{a}-\mathrm{e}$ & 4.00 & a \\
\hline Bush cinquefoil & 3.11 & $\mathrm{c}-\mathrm{f}$ & 3.44 & $\mathrm{a}-\mathrm{e}$ & 3.78 & $\mathrm{a}-\mathrm{c}$ \\
\hline Buttercup winterhazel & 2.11 & hi & 3.22 & $c-f$ & 3.89 & $\mathrm{ab}$ \\
\hline Common ninebark & 2.22 & gh & 3.89 & $\mathrm{ab}$ & 4.00 & a \\
\hline Common seabuckthorn & 1.89 & hi & 3.00 & ef & 3.33 & c \\
\hline Doublefile viburnum & 1.25 & $\mathrm{jk}$ & 2.88 & ef & & \\
\hline English ivy & 1.00 & $\mathrm{k}$ & 1.11 & $\mathrm{i}$ & & \\
\hline Fragrant viburnum & 1.33 & $\mathrm{jk}$ & 1.67 & gh & & \\
\hline Fuzzy deutzia & 3.33 & $\mathrm{~b}-\mathrm{e}$ & 3.67 & $\mathrm{a}-\mathrm{d}$ & 3.83 & $a-c$ \\
\hline Glossy abelia & 3.00 & $d-f$ & 4.00 & $\mathrm{a}$ & 4.00 & a \\
\hline Goldencup st. johnswort & 3.33 & $\mathrm{~b}-\mathrm{e}$ & 4.00 & $\mathrm{a}$ & 4.00 & $\mathrm{a}$ \\
\hline Hybrid deutzia & 3.00 & $d-f$ & 3.22 & $c-f$ & 3.78 & $a-c$ \\
\hline Japanese kerria & 3.44 & $\mathrm{a}-\mathrm{d}$ & 3.67 & $\mathrm{a}-\mathrm{d}$ & 3.78 & $a-c$ \\
\hline Privet honeysuckle & 1.00 & $\mathrm{k}$ & 1.44 & hi & 1.33 & $\mathrm{e}$ \\
\hline Purpleosier willow & 3.22 & $\mathrm{~b}-\mathrm{e}$ & 3.78 & $\mathrm{a}-\mathrm{c}$ & 3.89 & $\mathrm{ab}$ \\
\hline Redosier dogwood & 1.67 & $\mathrm{ij}$ & 3.11 & $\mathrm{~d}-\mathrm{f}$ & 3.56 & $a-c$ \\
\hline Scorpion senna & 3.67 & $a b$ & 3.78 & ac & 3.67 & $a-c$ \\
\hline Shrub althea & 2.22 & gh & 3.44 & $\mathrm{a}-\mathrm{e}$ & 3.78 & $\mathrm{a}-\mathrm{c}$ \\
\hline Slender deutzia & 2.00 & hi & 2.89 & ef & 3.38 & bc \\
\hline Spanish broom & 3.56 & $a-c$ & 4.00 & $\mathrm{a}$ & 4.00 & $\mathrm{a}$ \\
\hline Spanish gorse & 1.11 & $\mathrm{k}$ & 2.00 & $\mathrm{~g}$ & 2.17 & d \\
\hline Virginal mock orange & 2.67 & fg & 3.44 & $\mathrm{a}-\mathrm{e}$ & 3.89 & $\mathrm{ab}$ \\
\hline \multicolumn{7}{|l|}{ Weed management (WM) } \\
\hline Polypropylene fabric & 2.77 & $\mathrm{a}$ & 3.31 & $\mathrm{a}$ & 3.77 & $\mathrm{a}$ \\
\hline Biodegradable textile & 2.36 & $\mathrm{~b}$ & 3.49 & $\mathrm{a}$ & 3.77 & $\mathrm{a}$ \\
\hline Bare soil & 2.19 & $\mathrm{c}$ & 2.68 & $\mathrm{~b}$ & 3.35 & b \\
\hline \multicolumn{7}{|l|}{ Probability } \\
\hline SP & \multicolumn{2}{|c|}{$* * *$} & \multicolumn{2}{|c|}{$* * *$} & \multicolumn{2}{|c|}{$* * *$} \\
\hline WM & \multicolumn{2}{|c|}{$* * *$} & \multicolumn{2}{|c|}{$* * *$} & \multicolumn{2}{|c|}{$* * *$} \\
\hline $\mathrm{SP} \times \mathrm{WM}$ & \multicolumn{2}{|c|}{ NS } & \multicolumn{2}{|c|}{ NS } & \multicolumn{2}{|c|}{ NS } \\
\hline
\end{tabular}

${ }^{2}$ Groundcover percentage was assessed visually: $1=<25 \%, 2=25 \%$ to $50 \%, 3=50 \%$ to $75 \%, 4=>75 \%$.

${ }^{y}$ Means for each main factor and within each column followed by the same letter are not significantly different $(P \leq$ 0.05 ) according to Duncan's multiple range test.

NS, ${ }^{* *}$ Nonsignificant or significant at $P \leq 0.001$, respectively.

starting from the first growing season, whereas from the 2 nd year of trial both the tested mulches significantly increased the canopy coverage in comparison with the bare soil (Table 4).

An interaction between species and soil management was detected for plant shoot biomass (data not shown). When statistical differences were detected, plants mulched with polypropylene fabric showed higher shoot biomass compared with plants grown in bare soil with the only exception of scorpion senna (Table 5 ). Boxleaf and privet honeysuckle, redosier dogwood, and scorpion senna mulched with biodegradable textile showed a greater shoot biomass compared with plants grown in bare soil (Table 5 ). As reported by Harris et al. (2004), mulching can increase soil water content by increasing percolation and retention, reducing evaporation and weed competition; moreover mulches can protect soils from extreme temperatures, keeping it cooler in hot conditions and warmer in cold conditions (ChalkerScott, 2007; Einert et al., 1975; Ferrini et al., 2009; Long et al., 2001). The beneficial effect of mulches can explain, in species sensitive to water stress, the greater plant biomass compared with 
non-mulched plants; the degradation of biodegradable textile may have partially reduced the mulching effect in buttercup winterhazel, common seabuckthorn, japanese kerria, shrub althea, and slender deutzia.

Soil covering with mulching materials did not affect shrub althea and goldencup st. johnswort chlorophyll content in June 2009; however, in the second assessment (carried out in early July) goldencup st. johnswort plants mulched with polypropylene textile showed a higher chlorophyll content than those growing on bare soil (Table 6). As reported in literature, $F_{\mathrm{v}} / F \mathrm{~m}$ ratio is a reliable indicator of the occurrence of environmental stresses, including water stress, on photosystem II of several woody and herbaceous species (Angelopulos et al., 1996; Lazár, 2006; Maxwell and Johnson, 2000; Percival and Fraser, 2001; Percival et al., 2006; Yamada et al., 1996). $F_{\mathrm{V}} / F \mathrm{~m}$ ratio was not influenced by mulching in goldencup st. johnswort, whereas it was positively affected by polypropylene mulching in shrub althea (Table 6). This finding was also confirmed by chlorophyll a fluorescence transients, which provided evidence that shrub althea mulched with polypropylene fabric was less stressed during Aug. 2009 (Fig. 2). Shrub althea plants grown in bare soil or mulched with biodegradable textile highlighted changes in the acceptor side of photosystem I (IP-phase) (Tóth et al., 2007). In goldencup st. johnswort, chlorophyll a fluorescence transients were little affected by mulching; non-mulched plants showed moderate changes in the redox state of plastoquinone (JI-phase) and in IP-phase compared with plants mulched with polypropylene fabric (data not shown). A relationship between lower stress and higher shoot biomass of shrubs althea mulched with polypropylene can be assumed.

When vegetation is considered in models of slope stability, usually the only root parameters considered are tensile strength and root area ratio (Preti and Giadrossich, 2009; Tosi, 2007), but also the density and thickness of roots play a major role. Thin and fine roots are largely responsible for reinforcing soil on slopes; they act like soil nails on slopes, reinforcing soil (Ganatsas and Tsakaldimi, 2003; Stokes et al., 2009). In our experiment, the root system of plants grown

Table 5. Fresh shoot biomass of 25 shrubs grown on a slope under different types of soil management (bare soil and mulched with biodegradable textile or polypropylene fabric) at the end of the third growing season.

\begin{tabular}{|c|c|c|c|c|c|c|c|}
\hline \multirow{3}{*}{$\frac{\text { Species }}{\text { Blue-spirea }}$} & \multicolumn{6}{|c|}{ Fresh shoot biomass $(\mathrm{g} / \text { plant })^{\mathrm{z}}$} & \multirow{3}{*}{$\frac{\text { Probability }}{\text { NS }}$} \\
\hline & \multicolumn{2}{|c|}{$\begin{array}{c}\text { Polypropylene } \\
\text { fabric }\end{array}$} & \multicolumn{2}{|c|}{$\begin{array}{c}\text { Biodegradable } \\
\text { textile }\end{array}$} & \multicolumn{2}{|c|}{ Bare soil } & \\
\hline & 558 & $a^{y}$ & 634 & $\mathrm{a}$ & 546 & $\mathrm{a}$ & \\
\hline Border forsythia & 1323 & a & 1310 & $\mathrm{a}$ & 887 & $\mathrm{a}$ & NS \\
\hline Boxleaf honeysuckle & 1359 & $\mathrm{a}$ & 1214 & $\mathrm{a}$ & 643 & $\mathrm{~b}$ & * \\
\hline Bumald spirea & 766 & $\mathrm{a}$ & 910 & $\mathrm{a}$ & 624 & $\mathrm{a}$ & NS \\
\hline Bush cinquefoil & 355 & a & 327 & a & 261 & $\mathrm{a}$ & NS \\
\hline Buttercup winterhazel & 789 & $\mathrm{a}$ & 463 & $\mathrm{~b}$ & 375 & $\mathrm{~b}$ & *** \\
\hline Common ninebark & 920 & $\mathrm{a}$ & 1004 & $\mathrm{a}$ & 1108 & $\mathrm{a}$ & NS \\
\hline Common seabuckthorn & 2035 & $\mathrm{a}$ & 1159 & $\mathrm{~b}$ & 483 & $\mathrm{~b}$ & $* * *$ \\
\hline Fuzzy deutzia & 924 & $\mathrm{a}$ & 1252 & $\mathrm{a}$ & 659 & $\mathrm{a}$ & NS \\
\hline Glossy abelia & 959 & $\mathrm{a}$ & 1011 & a & 909 & $\mathrm{a}$ & NS \\
\hline Goldencup st. johnswort & 1410 & $\mathrm{a}$ & 1461 & $\mathrm{a}$ & 1255 & $\mathrm{a}$ & NS \\
\hline Hybrid deutzia & 830 & a & 1076 & $\mathrm{a}$ & 726 & $\mathrm{a}$ & NS \\
\hline Japanese kerria & 1005 & $\mathrm{a}$ & 483 & $\mathrm{~b}$ & 605 & $\mathrm{~b}$ & * \\
\hline Privet honeysuckle & 445 & $\mathrm{a}$ & 402 & $\mathrm{a}$ & 126 & $\mathrm{~b}$ & ** \\
\hline Purpleosier willow & 1070 & $\mathrm{a}$ & 960 & $\mathrm{a}$ & 863 & $\mathrm{a}$ & NS \\
\hline Redosier dogwood & 358 & $\mathrm{a}$ & 318 & $\mathrm{a}$ & 152 & $\mathrm{~b}$ & *** \\
\hline Scorpion senna & 2034 & $\mathrm{ab}$ & 2800 & $\mathrm{a}$ & 1190 & $\mathrm{~b}$ & ** \\
\hline Shrub althea & 1130 & a & 851 & $\mathrm{ab}$ & 640 & $\mathrm{~b}$ & * \\
\hline Slender deutzia & 480 & a & 356 & $\mathrm{~b}$ & 335 & $\mathrm{~b}$ & ** \\
\hline Spanish broom & 2883 & $\mathrm{a}$ & 3508 & $\mathrm{a}$ & 3014 & $\mathrm{a}$ & NS \\
\hline Spanish gorse & 437 & $\mathrm{a}$ & 368 & $\mathrm{a}$ & 331 & $\mathrm{a}$ & NS \\
\hline Virginal mock orange & 751 & $\mathrm{a}$ & 784 & $\mathrm{a}$ & 750 & $\mathrm{a}$ & NS \\
\hline
\end{tabular}

${ }^{\mathrm{z}} 1 \mathrm{~g}=0.0353 \mathrm{oz}$.

${ }^{y}$ Means within the same row followed by different letters are significantly different from each other using the Duncan's mean separation test.

$\mathrm{NS},{ }^{*},{ }^{* *},{ }^{* * *}$ indicate nonsignificant, significant at $P \leq 0.05,0.01$, or 0.001 , respectively.

Table 6. Chlorophyll content and chlorophyll fluorescence $(F \mathrm{v} / F \mathrm{~m})$ in shrub althea and goldencup st. johnswort grown on a slope with different soil cover managements (bare soil and mulched with biodegradable textile or polypropylene fabric). Data were collected during the third growing season after transplanting.

\begin{tabular}{|c|c|c|c|c|c|c|}
\hline \multirow[b]{2}{*}{$\begin{array}{l}\text { Soil cover } \\
\text { management }\end{array}$} & \multicolumn{3}{|c|}{$\begin{array}{l}\text { Chlorophyll } \\
\text { content }^{\mathrm{z}}\end{array}$} & \multicolumn{3}{|c|}{$\begin{array}{l}\text { Chlorophyll fluorescence } \\
\qquad\left(F_{\mathrm{v}} / F_{\mathrm{m}}\right)^{\mathrm{y}}\end{array}$} \\
\hline & $\begin{array}{l}25 \text { June } \\
2009\end{array}$ & $\begin{array}{l}3 \text { July } \\
2009\end{array}$ & $\begin{array}{l}6 \text { Aug. } \\
2009\end{array}$ & $\begin{array}{l}3 \text { July } \\
2009\end{array}$ & $\begin{array}{l}6 \text { Aug. } \\
2009\end{array}$ & $\begin{array}{l}26 \text { Aug. } \\
2009\end{array}$ \\
\hline \multicolumn{7}{|l|}{ Shrub althea } \\
\hline Polypropylene fabric & 41.3 & 42.3 & 44.6 & 0.823 & $0.819 \mathrm{a}^{\mathrm{x}}$ & $0.818 \mathrm{a}$ \\
\hline Biodegradable textile & 41.7 & 40.5 & 42.3 & 0.796 & $0.770 \mathrm{~b}$ & $0.763 \mathrm{~b}$ \\
\hline Bare soil & 40.1 & 41.4 & 42.3 & 0.788 & $0.759 \mathrm{~b}$ & $0.748 \mathrm{~b}$ \\
\hline Significance & NS & NS & NS & NS & $* *$ & $* * *$ \\
\hline \multicolumn{7}{|l|}{ Goldencup st. johnswort } \\
\hline Polypropylene fabric & 55.1 & $57.5 \mathrm{a}$ & 49.3 & 0.716 & 0.748 & 0.757 \\
\hline Biodegradable textile & 54.8 & $55.0 \mathrm{ab}$ & 50.2 & 0.717 & 0.756 & 0.726 \\
\hline Bare soil & 52.2 & $52.6 \mathrm{~b}$ & 46.2 & 0.702 & 0.723 & 0.711 \\
\hline Significance & NS & * & NS & NS & NS & NS \\
\hline
\end{tabular}

in bare soil had higher specific root length than mulched plants at both soil depth zone investigated; no differences between mulching materials were observed (Table 7). Among species, the highest specific root length roots, in the first $10-\mathrm{cm}$ soil depth, were observed in privet honeysuckle 


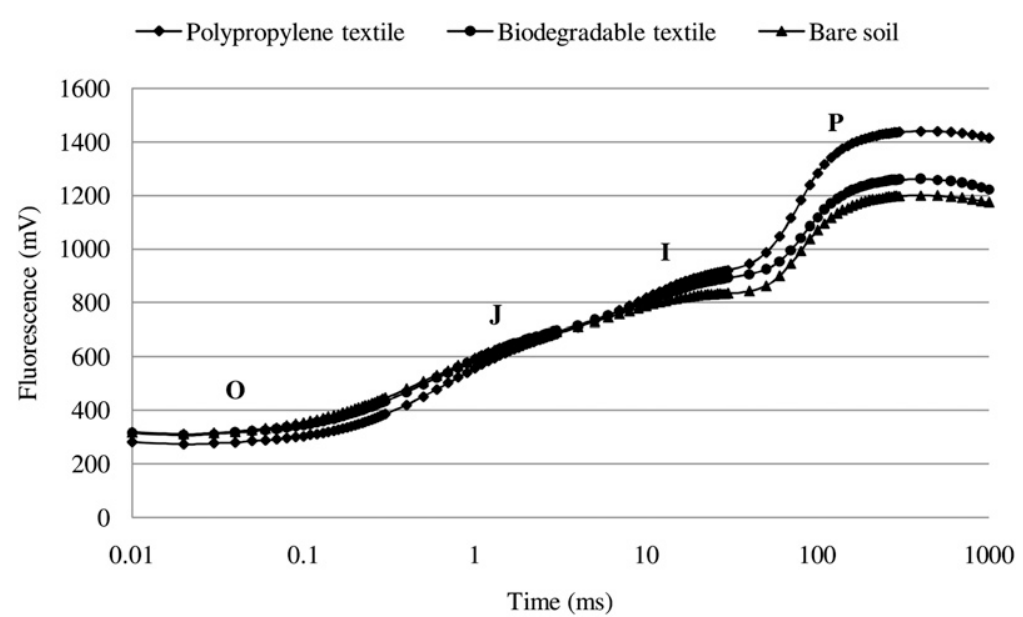

Fig. 2. Chlorophyll $a$ fluorescence induction curves in shrub althea grown on a slope with different soil cover managements (polypropylene textile, biodegradable textile, and bare soil). Data collected on 26 Aug. 2009. Each single curve represents the average of 10 independent chlorophyll fluorescence measurements; $\mathrm{O}$ step = fluorescence intensity at $50 \mu \mathrm{s}$, J step = fluorescence intensity at $2 \mathrm{~ms}$, I step = fluorescence intensity at $\mathbf{3 0} \mathrm{ms}, \mathbf{P}$ step = maximal fluorescence intensity .

Table 7. Root density (root length/soil volume) and specific root length (root length/dry root biomass), recorded at two soil depths [0-10 cm (3.9 inches) and $10-25 \mathrm{~cm}$ (9.8 inches) soil depth] in 25 shrubs grown on a slope under different types of soil management (bare soil and mulched with biodegradable textile or polypropylene fabric) at the end of the third growing season.

\begin{tabular}{|c|c|c|c|c|}
\hline \multirow[b]{3}{*}{ Species (SP) } & \multicolumn{2}{|c|}{$\begin{array}{l}\text { Root density }\left(\mathrm{m} \cdot \mathrm{L}^{-1}\right)^{\mathrm{z}} \\
\text { at soil depth }\end{array}$} & \multicolumn{2}{|c|}{$\begin{array}{l}\text { Specific root length } \\
\left(\mathrm{m} \cdot \mathrm{g}^{-1}\right)^{\mathrm{z}} \text { at soil depth }\end{array}$} \\
\hline & $0-10 \mathrm{~cm}$ & $10-25 \mathrm{~cm}$ & $0-10 \mathrm{~cm}$ & $10-25 \mathrm{~cm}$ \\
\hline & & & & \\
\hline Blue-spirea & $3.0 \mathrm{~h}^{\mathrm{y}}$ & $1.4 \mathrm{f}$ & $5.7 \mathrm{e}$ & $5.5 \mathrm{~b}$ \\
\hline Border forsythia & $17.5 \mathrm{bc}$ & $14.8 \mathrm{a}$ & $8.2 \mathrm{~d}-\mathrm{e}$ & $5.6 \mathrm{~b}$ \\
\hline Boxleaf honeysuckle & $12.2 \mathrm{~b}-\mathrm{f}$ & $5.2 \mathrm{~b}-\mathrm{e}$ & 14.2 a-e & $7.0 \mathrm{~b}$ \\
\hline Bumald spirea & $11.2 \quad \mathrm{c}-\mathrm{g}$ & $5.3 \mathrm{~b}-\mathrm{e}$ & 16.8 a-e & $7.7 \mathrm{~b}$ \\
\hline Bush cinquefoil & $7.8 \mathrm{e}-\mathrm{h}$ & $4.3 \mathrm{c}-\mathrm{f}$ & $11.7 \mathrm{~b}-\mathrm{e}$ & $11.2 \mathrm{ab}$ \\
\hline Buttercup winterhazel & $9.4 \mathrm{~d}-\mathrm{h}$ & $7.9 \mathrm{bc}$ & $10.7 \mathrm{c}-\mathrm{e}$ & $7.2 \mathrm{~b}$ \\
\hline Common ninebark & $12.3 \mathrm{~b}-\mathrm{f}$ & $6.0 \mathrm{~b}-\mathrm{d}$ & $11.3 \mathrm{c}-\mathrm{e}$ & $6.2 \mathrm{~b}$ \\
\hline Common seabuckthorn & $5.8 \mathrm{f}-\mathrm{h}$ & $3.1 \mathrm{~d}-\mathrm{f}$ & $12.2 \mathrm{~b}-\mathrm{e}$ & $5.5 \mathrm{~b}$ \\
\hline Fuzzy deutzia & 28.7 a & $12.2 \mathrm{a}$ & $17.6 \mathrm{a}-\mathrm{d}$ & $10.9 \mathrm{ab}$ \\
\hline Glossy abelia & $10.5 \mathrm{~d}-\mathrm{g}$ & $4.1 \mathrm{c}-\mathrm{f}$ & 13.7 b-e & $6.7 \mathrm{~b}$ \\
\hline Goldencup st. johnswort & $13.0 \mathrm{~b}-\mathrm{e}$ & $4.3 \mathrm{c}-\mathrm{f}$ & $16.3 \mathrm{a}-\mathrm{e}$ & $9.5 \mathrm{ab}$ \\
\hline Hybrid deutzia & $19.0 \mathrm{~b}$ & $8.2 \mathrm{~b}$ & 16.5 a-e & $7.8 \mathrm{~b}$ \\
\hline Japanese kerria & $12.2 \mathrm{~b}-\mathrm{f}$ & $5.4 \mathrm{~b}-\mathrm{e}$ & $8.3 \mathrm{~d}-\mathrm{e}$ & $8.1 \mathrm{~b}$ \\
\hline Privet honeysuckle & $7.0 \mathrm{e}-\mathrm{h}$ & $4.2 \mathrm{c}-\mathrm{f}$ & 24.8 a & $9.2 \mathrm{ab}$ \\
\hline Purpleosier willow & $5.0 \mathrm{gh}$ & $3.1 \mathrm{~d}-\mathrm{f}$ & $12.6 \mathrm{~b}-\mathrm{e}$ & $7.1 \mathrm{~b}$ \\
\hline Redosier dogwood & $8.8 \mathrm{~d}-\mathrm{h}$ & $5.6 \mathrm{~b}-\mathrm{e}$ & $9.6 \mathrm{~d}-\mathrm{e}$ & $7.1 \mathrm{~b}$ \\
\hline Scorpion senna & $4.1 \mathrm{gh}$ & $3.6 \mathrm{~d}-\mathrm{f}$ & $8.6 \mathrm{~d}-\mathrm{e}$ & $5.7 \mathrm{~b}$ \\
\hline Shrub althea & $13.9 \mathrm{~b}-\mathrm{e}$ & $7.5 \mathrm{bc}$ & $13.0 \quad \mathrm{~b}-\mathrm{e}$ & $5.3 \mathrm{~b}$ \\
\hline Slender deutzia & $8.4 \mathrm{~d}-\mathrm{h}$ & $3.5 \mathrm{~d}-\mathrm{f}$ & $21.1 \quad \mathrm{a}-\mathrm{c}$ & $15.1 \mathrm{a}$ \\
\hline Spanish broom & $4.4 \mathrm{gh}$ & $3.0 \mathrm{~d}-\mathrm{f}$ & $8.5 \mathrm{~d}-\mathrm{e}$ & $5.0 \mathrm{~b}$ \\
\hline Spanish gorse & $4.6 \mathrm{gh}$ & $2.1 \mathrm{ef}$ & $22.6 \mathrm{ab}$ & $9.6 \mathrm{ab}$ \\
\hline Virginal mock orange & $14.9 \mathrm{~b}-\mathrm{d}$ & $8.1 \mathrm{~b}$ & $22.7 \mathrm{ab}$ & $10.3 \mathrm{ab}$ \\
\hline \multicolumn{5}{|l|}{ Weed management (WM) } \\
\hline Polypropylene fabric & $6.5 \mathrm{c}$ & $3.9 \mathrm{~b}$ & $10.3 \mathrm{~b}$ & $6.8 \mathrm{~b}$ \\
\hline Biodegradable textile & $10.7 \mathrm{~b}$ & $6.2 \mathrm{a}$ & $12.0 \mathrm{~b}$ & $7.4 \mathrm{~b}$ \\
\hline Bare soil & $14.6 \mathrm{a}$ & $6.8 \mathrm{a}$ & $19.6 \mathrm{a}$ & 9.4 a \\
\hline \multicolumn{5}{|l|}{ Probability } \\
\hline SP & $* * *$ & *** & *** & * \\
\hline WM & $* * *$ & $* * *$ & *** & * \\
\hline $\mathrm{SP} \times \mathrm{WM}$ & $* * *$ & NS & NS & NS \\
\hline
\end{tabular}

${ }^{\mathrm{z}} \mathrm{lm} \cdot \mathrm{L}^{-1}=12.4193 \mathrm{ft} / \mathrm{gal}, \mathrm{l} \mathrm{m} \cdot \mathrm{g}^{-1}=93.0102 \mathrm{ft} / \mathrm{oz}$.

y Means for each main factor and within each column followed by the same letter are not significantly different ( $P \leq$ 0.05 ) according to Duncan's multiple range test.

NS, $* * *$ Nonsignificant or significant at $P \leq 0.001$, respectively. while blue-spirea had the lowest. In the deeper soil zone (between 10 and $25 \mathrm{~cm}$ ), slender deutzia showed the highest specific root length; bush cinquefoil, fuzzy deutzia, goldencup st. johnswort, privet honeysuckle, spanish gorse, and virginal mock orange did not show significant differences from slender deutzia for this parameter (Table 7). As reported in Table 7 , in the shallower soil zone an interaction between species and soil management was detected for root density. When significant differences were found, the highest root density was observed in plant grown in bare soil, whereas the lowest values were reported in plants mulched with polypropylene fabric, with the exception of fuzzy deutzia. In this species, the highest root density was observed in plants mulched with biodegradable textile (Table 8). In the deeper soil zone (between 10 and $25 \mathrm{~cm}$ ), the greater root density was observed in plants grown using biodegradable mulching and bare soil, whereas the lowest values were observed in plants mulched with polypropylene fabric (Table 7). Border forsythia and fuzzy deutzia showed the highest root density values at this depth, whereas the lowest values were detected in blue-spirea (Table 7). No significant differences in root density from blue-spirea were reported for bush cinquefoil, common seabuckthorn, glossy abelia, goldencup st. johnswort, privet honeysuckle, purpleosier willow, scorpion senna, slender deutzia, spanish broom, and spanish gorse at the 10-25-cm depth (Table 7). The higher root density and the higher specific root length detected in plants grown in bare soil can be probably explained by the necessity of the plant to explore the soil to reach for water. As reported by several authors mulched soil has greater water retention than bare soil (Chalker-Scott, 2007).

The type of soil management did not affect plant phenological stages and plant susceptibility to diseases or pests (data not shown). Septoria (Septoria cornicola) caused severe leaf damage on redosier dogwood, leading to early leaf fall. Aphids were detected on young shoots of goldencup st. johnswort, japanese kerria, scorpion senna, shrub althea, spanish broom, and virginal mock orange, but the damage was cosmetic.

Results of this study showed that mulching increased shoot biomass in 
Table 8. Root density (root length/soil volume), recorded in the first $10-\mathrm{cm}(3.9$ inches) soil depth, in $\mathbf{2 5}$ shrubs grown on a slope under different types of soil management (bare soil and mulched with biodegradable textile or polypropylene fabric) at the end of the third growing season.

\begin{tabular}{|c|c|c|c|c|c|c|c|}
\hline \multirow{3}{*}{$\frac{\text { Species }}{\text { Blue-spirea }}$} & \multicolumn{6}{|c|}{ Root density $\left(\mathrm{m} \cdot \mathrm{L}^{-1}\right)$ up to $10-\mathrm{cm}$ soil depth ${ }^{\mathrm{z}}$} & \multirow{3}{*}{$\frac{\text { Probability }}{\text { NS }}$} \\
\hline & \multicolumn{2}{|c|}{$\begin{array}{c}\text { Polypropylene } \\
\text { fabric }\end{array}$} & \multicolumn{2}{|c|}{$\begin{array}{c}\text { Biodegradable } \\
\text { textile }\end{array}$} & \multicolumn{2}{|c|}{ Bare soil } & \\
\hline & 2.4 & $a^{y}$ & 1.7 & $\mathrm{a}$ & 4.9 & a & \\
\hline Border forsythia & 17.4 & $\mathrm{a}$ & 7.3 & a & 27.9 & a & NS \\
\hline Boxleaf honeysuckle & 12.0 & $\mathrm{a}$ & 13.4 & $\mathrm{a}$ & 11.2 & $\mathrm{a}$ & NS \\
\hline Bumald spirea & 11.1 & $\mathrm{a}$ & 6.8 & $\mathrm{a}$ & 15.6 & $\mathrm{a}$ & NS \\
\hline Bush cinquefoil & 4.4 & $\mathrm{a}$ & 9.1 & $\mathrm{a}$ & 9.7 & a & NS \\
\hline $\begin{array}{l}\text { Buttercup } \\
\text { winterhazel }\end{array}$ & 8.3 & $\mathrm{a}$ & 10.1 & $\mathrm{a}$ & 10.0 & $\mathrm{a}$ & NS \\
\hline Common ninebark & 4.2 & $\mathrm{a}$ & 13.6 & $\mathrm{a}$ & 19.0 & $\mathrm{a}$ & NS \\
\hline $\begin{array}{l}\text { Common } \\
\text { seabuckthorn }\end{array}$ & 3.0 & $\mathrm{a}$ & 8.2 & a & 6.2 & a & NS \\
\hline Fuzzy deutzia & 11.9 & $\mathrm{~b}$ & 45.5 & $\mathrm{a}$ & 28.8 & $\mathrm{ab}$ & * \\
\hline Glossy abelia & 6.3 & $\mathrm{a}$ & 8.8 & $\mathrm{a}$ & 16.4 & $\mathrm{a}$ & NS \\
\hline $\begin{array}{l}\text { Goldencup st. } \\
\text { johnswort }\end{array}$ & 4.6 & $\mathrm{~b}$ & 11.1 & $\mathrm{~b}$ & 23.5 & a & $* *$ \\
\hline Hybrid deutzia & 8.9 & $\mathrm{~b}$ & 19.7 & $a b$ & 28.5 & a & $* *$ \\
\hline Japanese kerria & 4.6 & $\mathrm{a}$ & 18.9 & $\mathrm{a}$ & 13.2 & $\mathrm{a}$ & NS \\
\hline Privet honeysuckle & 6.9 & $\mathrm{a}$ & 5.7 & $\mathrm{a}$ & 8.3 & $\mathrm{a}$ & NS \\
\hline Purpleosier willow & 3.7 & $\mathrm{a}$ & 3.7 & $\mathrm{a}$ & 7.7 & $\mathrm{a}$ & NS \\
\hline Redosier dogwood & 4.9 & $\mathrm{~b}$ & 5.9 & b & 15.4 & $\mathrm{a}$ & $* *$ \\
\hline Scorpion senna & 2.1 & $\mathrm{~b}$ & 3.5 & $\mathrm{ab}$ & 6.8 & $\mathrm{a}$ & * \\
\hline Shrub althea & 12.0 & $\mathrm{a}$ & 11.8 & $\mathrm{a}$ & 17.8 & $\mathrm{a}$ & NS \\
\hline Slender deutzia & 2.5 & $\mathrm{a}$ & 7.7 & $\mathrm{a}$ & 14.8 & $\mathrm{a}$ & NS \\
\hline Spanish broom & 4.6 & $\mathrm{a}$ & 3.4 & $\mathrm{a}$ & 5.3 & $\mathrm{a}$ & NS \\
\hline Spanish gorse & 1.4 & $\mathrm{~b}$ & 5.2 & $\mathrm{ab}$ & 7.3 & $\mathrm{a}$ & * \\
\hline $\begin{array}{l}\text { Virginal mock } \\
\text { orange }\end{array}$ & 5.7 & $\mathrm{~b}$ & 15.2 & $\mathrm{ab}$ & 23.9 & $\mathrm{a}$ & * \\
\hline
\end{tabular}

${ }^{2} 1 \mathrm{~m} \cdot \mathrm{L}^{-1}=12.4193 \mathrm{ft} / \mathrm{gal}$.

${ }^{y}$ Means within the same row followed by different letters are significantly different from each other using the Duncan's mean separation test.

NS,****,*** indicate nonsignificant, significant at $P \leq 0.05,0.01$, or 0.001 , respectively.

some species and reduced hand weeding time. However considerations are needed about this practice, especially when used on a slope area. As previously reported, the use of mulching leads to a lower root density and lower specific root length compared with bare soil management levels, involving higher management and associated costs (materials, setting an higher transplanting labor). Species or cultivars characterized by fast groundcover ability should be preferred in slope areas to limit the unfavorable effect of the weeds, especially in bare soil. Among the species tested, fuzzy deutzia and virginal mock orange showed a higher number of desirable qualities: fast groundcovering ability, reduced hand weeding time, plant shoot biomass unaffected by soil management and high root density and high specific root length. They should be considered as desirable species for the slopes along roads and highways in similar conditions to those of the experimental area.

\section{Literature cited}

Angelopulos, K., B. Dichio, and C. Xiloyannis. 1996. Inhibition of photosynthesis in olive trees (Olea europaea L.) during water stress and rewatering. J. Expt. Bot. 47:1093-1100.

Assone, S., P. Borsotto, E. Fiora, and S. Facciuoli Cerea. 2000. Sperimentazione relativa alle principali specie tappezzanti in vista di un possibile impiego nel verde urbano, p. 99-1 14. Proc. Natl. Congr. Il verde urbano, storico e contemporaneo: Problematiche legate alla gestione. Brusson, Italy.

Burroughs, R. 2010. Water-wise landscaping. Amer. Nurseryman 210(7):10-20.

Cazzuffi, D. and F. Tironi. 2003. Contribution of roots to slope stability: An overview of typical results for different plants, p. 101-105. Proc. Intl. Conf. Fast slope movements: Prediction and prevention for risk mitigation. Naples, Italy.

Chalker-Scott, L. 2007. Impact of mulches on landscape plants and the environmentA review. J. Environ. Hort. 25:239-249.

Einert, A.E., R. Guidry, and H. Huneycutt. 1975. Permanent mulches for landscaping plantings of dwarf crape myrtles. Amer. Nurseryman 142(9):62-65.

Ferrini, F., A. Fini, P. Frangi, and G. Amoroso. 2008. Mulching of ornamental trees: Effects on growth and physiology. Arboriculture Urban For. 34:157-162.

Ferrini, F., A. Fini, S. Pellegrini, A. Agnelli, M. Platinetti, P. Frangi, and G. Amoroso. 2009. Effect of two organic mulches on soil physical, chemical and biological properties, p. 31-39, In: G. Watson, L. Costello, B. Scharenbroch, and E.F. Gilman (eds.). The landscape below ground III. Intl. Soc. Arboriculture, Champaign, IL.

Franco, J.A., J.J. Martinez-Sanchez, J.A. Fernandez, and S. Bañon. 2006. Selection and nursery production of ornamental plants for landscaping and xerogardening in semiarid environment. J. Hort. Sci. Biotechnol. 81:3-17.

Ganatsas, P.P. and M.N. Tsakaldimi. 2003. Root system modification of Pinus brutia Ten. species under adverse ecological conditions. Proc. 8th Intl. Conf. Environ. Sci. Technol. 216-223.

Gray, D.H. and A.T. Leiser. 1982. Biotechnical slope protection and erosion control. Van Nostrand Reinhold, New York.

Gray, D.H. and R.B. Satir. 1996. Biotechnical and soil bioengineering slope stabilization: A practical guide for erosion control. Wiley-Interscience, New York.

Harris, R.W., J.R. Clark, and N.P. Matheny. 2004. Arboriculture: Integrated management of landscape trees, shrubs, and vines. 4th ed. Prentice Hall, Upper Saddle River, NJ.

Lazár, D. 2006. The polyphasic chlorophyll a fluorescence rise measured under high intensity of exciting light. Funct. Plant Biol. 33:9-30.

Long, C.E., B.L. Thorne, N.L. Breisch, and L.W. Douglas. 2001. Effect of organic and inorganic landscape mulches on subterranean termite (Isoptera: Rhinotermitidae) foraging activity. Environ. Entomol. 30:832-836.

Macdonald, K.B. and B. Witek. 1994. Management options for unstable bluffs in Puget Sound, Washington. Coastal erosion management studies. Vol. 8. Shorelands and Water Resources Program, Washington Department of Ecology, Olympia. 
Maxwell, K. and G.N. Johnson. 2000. Chlorophyll fluorescence-A practical guide. J. Expt. Bot. 51:659-668.

Morgan, R.P.C. and R.J. Rickson. 1994. Slope stabilization and erosion control: A bioengineering approach. E \& FN Spon, London.

Osmond, D.L., C.R. Crozier, and D.H. Hardy. 1997. Careful Soil Sampling-The Key to Reliable Soil Test Information. 18 Apr. 2011. <http://www.soil.ncsu.edu/ publications/Soilfacts/AG-439-30/>.

Percival, G.C. and G.A. Fraser. 2001. Measurement of the salinity and freezing tolerance of Crataegus genotypes using chlorophyll fluorescence. J. Arboriculture 27:233-245.

Percival, G.C., I.P. Keary, and K. Novis. 2008. The potential of a chlorophyll content SPAD meter to quantify nutrient stress in foliar tissue of sycamore (Acer psendoplatanus), english oak (Quercus robur), and european beech (Fagus sylvatica). Arboriculture Urban For. 34:89-100.

Percival, G.C., I.P. Keary, and S. Al-Habsi. 2006. An assessment of the drought tolerance of Fraxinus genotype for urban landscape planting. Urban For. Urban Green. 5:17-27.
Pinior, A., G. Grunewaldt-Stöcker, H. von Alten, and R.J. Strasser. 2005. Mycorrhizal impact on drought stress tolerance of rose plants probed by chlorophyll a fluorescence, proline content and visual scoring. Mycorrhiza 15:596-605.

Preti, F. and F. Giadrossich. 2009. Root reinforcement and slope bioengineering stabilization by spanish broom (Spartium junceum L.). Hydrol. Earth Syst. Sci. 13:1713-1726.

Rice, Jr., R.P. 1992. Nursery and landscape weed control manual. Thomson Publications, Fresno, CA.

Stinson, J.M., G.H. Brinen, D.B. McConnell, and R.J. Black. 1990. Evaluation of landscape mulches. Proc. Florida State Hort. Soc. 103:372-377.

Stokes, A., C. Atger, A.G. Bengough, T. Fourcaud, and R.C. Sidle. 2009. Desirable plant root traits for protecting natural and engineered slopes against landslides. Plant Soil 324:1-30.

Strasser, R.J., A. Srivastava, and M. TsimilliMichael. 2000. The fluorescence transient as a tool to characterize and screen photosynthetic samples, p. 445-483. In: M. Yunus (ed.). Probing photosynthesis: Mechanisms, regulation and adaptation. Taylor \& Francis, London.
Strasser, R.J. and M. Tsimilli-Michael. 2001. Stress in plants from daily rhythm to global changes, detected and quantified by JIP test. Chime Nouvelle (SRC) 75 : 3321-3326.

Tennant, D. 1975. A test of a modified line intersect method of estimating root length. J. Ecol. 63:995-1001.

Tóth, S.Z., G. Schansker, and R.J. Strasser. 2007. A non-invasive assay of the plastoquinone pool redox state based on the OJIP-transient. Photosyn. Res. 93: 193-203.

Tosi, M. 2007. Root tensile strength relationships and their slope stability implications of three shrub species in the northern Apennines (Italy). Geomorphology 87:268-283.

Yamada, M., D. Hidaka, and H. Fukamachi. 1996. Heat tolerance in leaves of tropical fruit crops as measured by chlorophyll fluorescence. Scientia Hort. 67:39-48.

Yeager, T., T. Bilderback, D. Fare, C.H. Gilliam, J. Lea-Cox, A. Niemiera, J. Ruter, K.M. Tilt, S.L. Warren, T. Whitwell, and R. Wright. 2006. Best management practices: Guide for producing nursery crops. 2nd ed. Southern Nursery Assn., Atlanta. 